\title{
Mais além da determinação social: sobredeterminação, sim!
}

\author{
Beyond social determination: \\ overdetermination, yes!
}

\section{Más allá de la determinación social: ¡sobredeterminación, sí!}

Cecília Minayo ${ }^{1}$ pretende demonstrar a impropriedade da ideia de "determinação social de saúde". Para ela, essa noção é incapaz de representar a complexidade de "todas as questões que envolvem o campo da Saúde Coletiva, frente ao contexto das profundas mudanças da sociedade pós-industrial” 1 (p. 1). Identifica suas raízes no positivismo e na vulgata marxista, como uma concepção substancialista da realidade, funcionalista do biológico e reificadora do social, insistindo que se trata de expressão originária da Epidemiologia e não do campo das Ciências Sociais e Saúde. Com base numa argumentação que mais parece um catálogo de falácias, termina prescrevendo a eliminação total do termo "determinação social", a ser "extirpado" do referencial científico da Saúde Coletiva.

Em seu texto-provocação, Minayo confunde propositalmente o princípio filosófico do determinismo, a categoria determinação e a noção de determinante. Isso constitui um caso flagrante de "falácia de pressuposto". O modo como apresenta um resumo da obra de alguns notórios teóricos europeus, induz o/a leitor/a a concluir que os formuladores da teoria da determinação social da saúde não defendem a abertura paradigmática das ciências nem a complexidade dos objetos de conhecimento da saúde-enfermidade-cuidado. Trata-se aqui de outra modalidade de falácia, a "falácia da falsa atribuição", facilmente desmascarada pela produção sobre complexidade e saúde de vários autores a quem ela duramente critica; como, por exemplo, Breilh 2.

Neste espaço limitado, não me é possível contestar ponto a ponto seu libelo de(con)strutivo. Prefiro mostrar em que medida e de que maneira temos avançado teoricamente para além da ideia de "determinação", reafirmando as bases filosóficas e políticas de nossa perspectiva, por ela contestadas. Para isso, pretendo indicar brevemente elementos estruturantes da crítica epistemológica ao determinismo realizada por autores criticados por Minayo ${ }^{1}$, numa perspectiva de superação dessa secular questão filosófica.

A categoria epistemológica da determinação tem sido potencialmente útil para modelar sucessões causais e processos de produção de efeitos, em muitos campos de conhecimento científico. Entretanto, limites heurísticos contraindicam sua aplicação generalizada a objetos complexos e singulares, passíveis de uma compreensão fundada na complexidade. Essa problemática teórica, no marco referencial do materialismo-histórico, tem sido tratada, e bem tratada, recorrendo à categoria "sobredeterminação".

A questão filosófica que fundamenta a ideia de "sobredeterminação" havia sido pioneiramente estabelecida por Marx, como projeto filosófico-político de superação da dialética hegeliana. Nesse
1 Universidade Federal da Bahia, Salvador, Brasil. 2 Instituto de Estudos Avançados, Universidade de São Paulo, São Paulo, Brasil.

Correspondência

N. Almeida-Filho Rua Waldemar Falcão 641, apto. 501, Salvador, BA 40295-010, Brasil. naomaralmeida@gmail.com 
aspecto, uma citação da Introdução à Crítica da Economia Política 3 (p. 14) ficou famosa: "o concreto é concreto porque é síntese de muitas determinações, isto é, unidade do diverso". Conforme apontado por Castiel 4 há mais de três décadas, o conceito de "sobredeterminação" foi cunhado por Freud para se referir à série articulada de causas e fatores desencadeantes dos sintomas das neuroses e das diversas formações do inconsciente, num modelo heurístico com base em quantidades de energia e massas em movimento provenientes de fontes endógenas e exógenas. Posteriormente, propôs o conceito para designar o processo de formação de cadeias de pensamentos, sobredeterminados no sentido de que sua origem remonta a séries de elementos que não necessariamente demonstram estreita relação mútua 4. Para abordar as formações do inconsciente como redes de significantes, Lacan recupera a proposição freudiana de múltipla determinação dos fenômenos psíquicos "no plano de sobredeterminação simbólica que chamamos de inconsciente do sujeito" 5 (p. 113). Na leitura lacaniana, numa perspectiva abertamente antiessencialista, efeitos emergentes na consciência (sonhos, lapsos, sintomas) "encontram-se sobredeterminados pelo real impossível, pelo real inconsciente, nossa maneira de nos encontrar, sempre de uma forma fracassada, com o real inconsciente" 5 (p. 68). No regime da sobredeterminação, forças fracas, parciais, contingentes, plásticas, virtuais e sempre dinâmicas, elementos de reduzido "valor psíquico", ganham potência juntos, criam vetores novos e mutantes de produção de efeitos, convergem para se tornarem forças fortes.

Diretamente influenciado por Lacan, Althusser 6 postula que o conceito de contradição em Marx supõe diversas instâncias da formação social que, para entendimento da interdeterminação de sua dinâmica histórica, precisariam de mais do que a multicausalidade. Assim, a sobredeterminação abre uma possibilidade de introduzir no marxismo uma lógica não-linear, na qual o processo produtivo coincide com a produção, com o produto, com o contexto e com a história. Essa categoria compreende uma releitura da dialética, implicando "fenômenos orgânicos de deslocamento e condensação" 6 (p. 173) que constituem a própria "identidade dos opostos" 6 (p. 174). Para Althusser 7, a parte contraditória de um sistema é sobredeterminada pelo todo desse sistema, quando as instâncias de determinação são, a um só tempo, determinantes e determinadas, em constante retroalimentação que, por sua vez, reflete uma contradição principal, sendo o todo complexo também produto dessa estrutura. Portanto, num esforço de compreensão totalizante da formação social, na perspectiva de sua transformação política, nenhuma das instâncias ou conjunto de fatores pode ser reduzido a uma causa ou deduzida a partir dela. Com base nesse conjunto de pressupostos gerais, Althusser 6 (p. 92) define o conceito de sobredeterminação como "acumulação de determinações eficazes saídas das superestruturas e de circunstâncias particulares sobre a determinação em última instância pela economia".

Longe de merecer a pecha preconceituosa de positivista ou funcionalista, a releitura althusseriana do concepto de sobredeterminação tem recebido críticas construtivas de vários autores, sobretudo em seus aspectos subjetivos, políticos e simbólicos. Numa perspectiva contracolonizadora, Laclau \& Mouffe 8 (p. 135) observam que a teoria althusseriana sustenta um importante postulado: "não há realidade que não seja sobredeterminada". Complementando Althusser, tomam a sobredeterminação como forma discursiva para priorizar as ideias de indeterminação e contingência, daí derivando um segundo postulado fundamental para sua teoria: "o social é constituído como uma ordem simbólica" 8 (p. 134). Avaliando que o conceito de sobredeterminação estrutura o campo da variação contingente, criticamente contraposto à ideia de "determinação essencial”, concluem que devemos buscar entendê-lo não como uma contradição estrutural, e sim pensá-lo na perspectiva gramsciana, como um complexo histórico-social mais amplo, de natureza conjuntural e contextual 8. Nessa mesma linha, Néstor Garcia-Canclini 9 (p. 123) afirma que os espaços simbólicos da vida social estão de muitas maneiras sobredeterminados, "posto que são indissociáveis o econômico e o simbólico, a força e o sentido, é impossível que um desses elementos se afaste da unidade social e determine privilegiadamente, por si só, toda a sociedade”.

No campo da saúde, Juan Samaja 10 identifica processos territoriais, sociais, culturais e políticos como objetos complexos, singulares e totalizantes, ao mesmo tempo ontológicos e heurísticos, polissêmicos, polimórficos, plurais, enunciados para (e por) referência às dimensões fenomênicas, sócio-históricas, imaginárias e simbólicas dos eventos-processos da vida-saúde-doença-morte. Tais objetos não se submetem à produção de conhecimento mediante fragmentação (são, portanto, aversos a processos analíticos), mas podem ser estudados por meio de sínteses e modelagens complexas. Para Samaja 10, a sobredeterminação é um conceito-chave para compreensão da reprodução social de processos saúde-enfermidade como objetos complexos, regidos por lógicas plurais. 
Numa perspectiva que denominamos holopatogênese 11,12, o objeto "saúde-enfermidade-cuidado" se define como plural e multifacetado, sendo a "enfermidade" simultaneamente defeito, lesão, alteração, patologia, doença, risco, dano; a "saúde”, um conjunto interarticulado de valores, medidas, temas e fenômenos; o "cuidado" compreende atos, modos e práticas de atenção à saúde. O complexo fenomênico em saúde, sobredeterminado por uma lógica de complexidade, pode ser construído sob a forma de uma "rede de sobredeterminação", em planos distintos de ocorrência, como, por exemplo a pandemia da COVID-19 13.

Para aplicar tais categorias, conceitos e estratégias na modelagem de objetos singulares com significativo grau de eficiência heurística, precisamos identificar subespaços ou planos de ocorrência, explorar suas formas de determinação, descrever objetos intermediários e delimitar interfaces estruturantes dos processos de totalização desses objetos, sempre sobredeterminados. Neste comentário, apenas reitero o que, junto a Coutinho e Luis David Castiel, formulamos na coletânea Epidemiologia er Saúde 14 (p. 42): "Além da possibilidade de suplantar tais limitações do modelo causal cartesiano e mesmo sua atualização probabilística, a categoria sobredeterminação permite incorporar a ideia da contingência como fator ou ponto desencadeador [tipping point] de trajetórias de determinação da doença $D$ ou de situações/estados de saúde S, na perspectiva de uma Teoria da Complexidade aplicada à Epidemiologia”.

Podemos falar de sobredeterminação enfim como uma categoria geral cujas modalidades seriam formas particulares de "sínteses de muitas determinações”. Essa abordagem permite atualizar a tipologia da causalidade geral de Bunge 15 , que propôs distinguir determinação causal, determinação dialética e determinação estrutural, entre outras. Porém, será mais interessante pensar numa aplicação específica para o campo da saúde, cobrindo vetores e fatores que podem ser referenciados por categorias particulares de processos determinantes. Assim, as modalidades da sobredeterminação em saúde seriam: causação nos planos biológicos e clínicos; determinação da situação e das condições de vida; construção de políticas e instituições de saúde; produção de práticas e modos de saúde; invenção dos sentidos e narrativas da saúde. O diferencial semântico sugerido entre os termos "determinação social”, "produção cultural”, “construção política” e "invenção simbólica” corresponderia, numa perspectiva epistemológica igualmente consistente, a diferentes planos da realidade e seus respectivos e distintos efeitos. No caso, do biológico-clínico ao ideológico-simbólico, passando pelo plano social, político-institucional e sociocultural.

A omissão no texto de Minayo ${ }^{1}$ dos desenvolvimentos conceituais aqui brevemente apresentados ilustra uma gravíssima falácia de "cancelamento". Temos honestamente tentado compreender (e não somente explicar) as raízes, determinações e contingências dos processos de saúde-enfermidade-cuidado, numa reflexão própria (e não submetida à vanguarda eurocêntrica), aplicando uma abordagem pluralista (mas não eclética) de forma livre e criativa, mas sempre radicalmente crítica. Com a devida "humildade epistemológica”, essa postulação nos permite propor que, no hipercapitalismo globalizado, o campo da saúde pode ser melhor pensado considerando uma sobredeterminação complexa de desigualdades estruturais e sistêmicas que, no cotidiano das sociedades contemporâneas, constituem fonte permanente de injustiça e iniquidades. Para uma compreensão profunda e sistemática dessa cruel realidade, a fim de transformá-la, precisamos recorrer a todas as formas da determinação, incluindo, certamente, a determinação social para ir mais além, na perspectiva ampla e totalizante da sobredeterminação. Sobredeterminação social, sim! 
Informação adicional

ORCID: Naomar Almeida-Filho (0000-0002-4435755X).

\section{Agradecimentos}

A Juan Samaja, in memoriam, a Asa Cristina Laurel e Jaime Breilh, pela inspiração pioneira.
1. Minayo MCS. Determinação social, não! Por quê? Cad Saúde Pública 2021; 37:e00010721.

2. Breilh J. Epidemiología del siglo XXI y ciberespacio: repensar la Teoría del Poder y la determinación social de la salud. Rev Bras Epidemiol 2015; 18:965-74.

3. Marx K. Para a crítica da economia política. São Paulo: Abril Cultural; 1982.

4. Castiel LD. Freud: um epidemiologista? Cad Saúde Pública 1988; 4:316-25.

5. Lacan J. Escritos. Ciudad de México: Siglo XXI; 2009.

6. Althusser L. Contradicción y sobredeterminación (notas para una investigación). In: Althusser L, organizador. La revolución teórica de Marx. Buenos Aires: Siglo XXI; 1967. p. 71106.

7. Althusser L. Sobre la dialéctica materialista (de la desigualdad de los orígenes). In: Althusser L, organizador. La revolución teórica de Marx. Buenos Aires: Siglo XXI; 1967. p. 132-80.

8. Laclau E, Mouffe C. Hegemonía y estrategia socialista. Buenos Aires: Fondo de Cultura Económica; 2004.

9. García-Canclini N. Diferentes, desiguales o desconectados. Revista CIDOB d'Afers Internacionals 2004; 66-67:113-33.

10. Samaja J. Desafios a la epidemiologia (pasos para una epidemiologia 'miltoniana'). Rev Bras Epidemiol 2003; 6:105-20.

11. Samaja J. Epistemología de la salud. Buenos Aires: Lugar Editorial; 2004.

12. Almeida-Filho N. Towards a unified theory of health-disease. II. Holopathogenesis. Rev Saúde Pública 2014; 48:192-205.

13. Almeida-Filho N. Modelagem da pandemia COVID-19 como objeto complexo (notas samajianas). Estud Av 2020; 34:97-117.

14. Coutinho D, Almeida-Filho N, Castiel LD. Epistemologia da epidemiologia (categorias de determinação: causalidade, predição, contingência, sobredeterminação). In: Almeida-Filho $\mathrm{N}$, Barreto M, organizadores. Epidemiologia \& saúde: fundamentos, métodos, aplicações. Rio de Janeiro: Editora Guanabara Koogan; 2011. p. 29-42.

15. Bunge M. El principio de la causalidad en la ciencia moderna. Buenos Aires: EUDEBA; 1969. 